\title{
Evaluation of Hepatoprotective Activity of Zanthoxylum armatum on Paracetamol-induced Liver Toxicity in Rats
}

\author{
M. R. TALLURI, VEDA PRIYA GUMMADI*, G. R. BATTU, AND K. N. KILLARI \\ AU College of Pharmaceutical Science, Andhra University, Visakhapatnam-530 003, India
}

Talluri et al.: Hepatoprotective Activity of Zanthoxylum armatum

\begin{abstract}
The present study was carried out to identify phytochemical compounds and to study the hepatoprotective activity of Zanthoxylum armatum rhizome. Phytochemical analysis was carried out using standard procedures to quantify total alkaloid and phenolic contents. Hepatoprotective activity was determined using paracetamol-induced hepatotoxicity in rats. Zanthoxylum armatum extracts showed the presence of steroids, terpenoids, flavonoids, alkaloids, glycosides, phenols, oils, tannins and carbohydrates. The methanol extract has more phenolic and alkaloid contents than other extracts. The methanol extract at $500 \mathrm{mg} / \mathrm{kg} \mathrm{showed}$ greater hepatoprotective activity with $66.87,64.84,67.95,60.76$ and $65.85 \%$ protection on aspartate aminotransferase, alanine aminotransferase, alkaline phosphatase, total bilirubin and total protein enzyme levels of the liver, respectively. The results of the present study and previous reports indicated that a variety of phytochemical constituents in Zanthoxylum armatum and its' extracts contributed to the observed antioxidant, antibacterial and hepatoprotective activities.
\end{abstract}

Key words: Paracetamol, phytochemical compounds, rhizome, Zanthoxylum armatum

The liver plays a vital role in physiological functions that include oxidation, reduction, hydrolysis, conjugations, sulfation and acetylation in detoxification along with carbohydrate, lipid and protein metabolism of the body ${ }^{[1,2]}$. If it did not function normally to regulate body metabolism, which reflects in alterations in different enzymes, hormones and proteins levels ${ }^{[3,4]}$. This will affect the health conditions of the human or any living organism leading to mortality ${ }^{[5]}$. So, it is very important to maintain a healthy liver to have a healthy body with effectively functioning organs. Nowadays, a variety of factors cause injury to different organs of the body including liver and these include microbial infections, environmental pollutants and toxic chemicals. In recent studies, hepatotoxic chemical or drugs are found to cause more liver diseases compared to spontaneous liver diseases. Simultaneously, oxidative stress also plays an important role in damaging liver tissue and it is one of the major causes for liver damage around the world ${ }^{[5-8]}$. Many drugs used to treat different diseases produce therapeutic benefit but also simultaneously cause side effects that at times lead to different organ damage in the body ${ }^{[3,9]}$. Antibacterial drugs on longterm usage become ineffective due to microorganisms acquiring resistant to these drugs ${ }^{[10]}$. The antibiotic- resistant microorganisms are a huge threat to global human health ${ }^{[11]}$. In this regard, identification of new drugs from various sources is very important to control the increasing disease burden including liver diseases and side effects of existing drugs ${ }^{[12]}$.

Identification of new active metabolites from medicinal plants has been proved to be the best approach since olden days mainly since herbal medicine has been the basis for current day drugs ${ }^{[13-15]}$. Indian Ayurveda, Chinese traditional medicine, Traditional Korean medicine, Unani medicine, Traditional African medicine were mainly based on medicinal plants ${ }^{[16-19]}$. In recent studies, various medicinal plants were reported to possess biological activities, bioactive metabolites, precursors for of new bioactive molecules and therapeutic potential against several diseases including hepatic injury ${ }^{[20-22]}$. However, many more medicinal plants still need to be investigated for potential biological activities that these might possess.

This is an open access article distributed under the terms of the Creative Commons Attribution-NonCommercial-ShareAlike 3.0 License, which allows others to remix, tweak, and build upon the work non-commercially, as long as the author is credited and the new creations are licensed under the identical terms

Accepted 10 December 2018

Revised 04 May 2018

Received 13 January 2018

Indian J Pharm Sci 2019;81(1):138-145 
Zanthoxylum armatum is one of the traditional medicinal plants used as an aromatic tonic in fever and dyspepsia, toothache, rheumatism and as a lotion for scabies while, fruits of this plant were used in the preparation of essential oils ${ }^{[23,24]}$. Because of its aromatic nature, it is also used as a deodorant and disinfectant. Some early reports on $Z$. armatum indicated that the leaves exhibited anticonvulsant and antispasmodic effects ${ }^{[25,26]}$, while the stem bark was cytotoxic and antioxidant ${ }^{[27]}$. However, there have been no published reports on the hepatoprotective ability and phytochemical composition of roots of $Z$. armatum except that a previous study from our laboratory reported antioxidant activity ${ }^{[28]}$.

\section{MATERIALS AND METHODS}

The solvents used in the present study were of analytical grade and the diagnostic kits for estimation of different enzymes levels were acquired from Span Diagnostics Ltd., Gujarat, India. The standard drug (Liv 52) and paracetamol were purchased from a local medical store, Visakhapatnam, India. Liv 52 is a multiherbal drug from Himalaya Global Holdings, which is used to treat chemically-induced hepatotoxicity.

\section{Preparation of extracts:}

The $Z$. armatum plant material was collected in the Tirupathi region and authenticated in the Department of Botany, Sri Venkateswara University, Tirupathi. The collected material was washed under running water and dried under shade. The dried plant material was made into coarse powder. The powdered material was extracted separately with ethyl acetate, chloroform and methanol using Soxhlet extraction procedure. The collected solutions were concentrated on a rotavap to obtain dry extracts, which were stored in desiccator and used for further studies.

\section{Phytochemical analysis:}

The collected extracts were tested for the presence or absence of different biologically active compounds and quantified the total phenolic, alkaloid contents using standard test procedures ${ }^{[2,29-32]}$.

\section{Experimental animals:}

To evaluate the hepatoprotective activity of Z. armatum, outbred Wistar albino rats (180-250 g) were used, which were obtained from M/s Mahaveer Enterprises, Hyderabad, India and the work was carried at College of Pharmaceutical Sciences, Andhra University, approved Committee for the Purpose of Control and Supervision of Experiments on Animals (CPCSEA), Government of India (Reg. No. 516/01/A/CPCSEA). Animals were maintained at controlled environmental conditions before and during the experiments $\left(22 \pm 2^{\circ}\right.$, $60 \pm 5 \%$ humidity). Animals were provided with standard laboratory diet and water.

\section{Acute toxicity study:}

The extracts of $Z$. armatum were tested for their toxicity as per Organisation for Economic Co-operation and Development test guideline $423^{[33]}$. Wistar rats of single sex (male; $n=6$ ) were grouped into three. After one week of maintenance at laboratory conditions, each group of animals were administered orally $2000 \mathrm{mg} / \mathrm{kg}$ of a test extract and the animals were kept under observation to monitor mortality, physiological and psychological condition such as skin changes, morbidity, aggressiveness, oral secretions, sensitivity to sound and pain and respiratory movements.

\section{Hepatoprotective activity of $Z$. aramatum:}

The ethyl acetate extract of $Z$. armatum (ZAEAE), chloroform extract (ZACE) and methanol extract (ZAME) were tested in the paracetamol-induced liver toxicity model ${ }^{[34]}$. The selected animals for the study were assigned to XII groups $(n=6)$, group I and II animals were administrated with normal saline for $7 \mathrm{~d}(2 \mathrm{ml} / \mathrm{kg})$, group III was administrated with Liv $52(25 \mathrm{mg} / \mathrm{kg})$, groups IV to VI were administrated with 125,250 and $500 \mathrm{mg} / \mathrm{kg}$ of ZAEAE, groups VII to VIII were administrated with 125,250 and $500 \mathrm{mg} / \mathrm{kg}$ of ZACE and groups X to XII were administrated with 125,250 and $500 \mathrm{mg} / \mathrm{kg}$ of ZAME extract for $7 \mathrm{~d}$. On the 5 th $\mathrm{d}$ of experiment excluding group I, all were treated with $200 \mathrm{mg} / \mathrm{kg}$ paracetamol. On the end of the experiment (day 7), $2 \mathrm{~h}$ after the administration of the final dose of test extracts, blood samples were collected through retro-orbital plexus from all animals under light anaesthesia. The collected samples were immediately centrifuged $(2400 \mathrm{rpm} /$ $15 \mathrm{~min}$ ) and the serum was separated. Serum was used to estimate liver functional parameters like aspartate aminotransferase (AST), alanine aminotransferase (ALT), alkaline phosphatase (ALP), total bilirubin and total protein content using an Autoanalyzer ${ }^{[2]}$ (RM4000, Biochemical systems International, Italy).

\section{RESULTS AND DISCUSSION}

Among different extracts of the selected plant, ZAME 
showed consistent and better activity compared to other extracts. So, based on these results and availability of extract, ZAME was used for isolation of pure compounds through column chromatography. Column chromatography was carried out using $10 \mathrm{~g}$ of extract with 60-120 mesh silica gel as absorbent. The column was eluted in a gradient approach with hexane, hexaneethyl acetate, ethyl acetate, ethyl acetate-methanol mixtures from $100 \%$ hexane to $100 \%$ methanol with increasing polarity. A mixture of white crystals was isolated at $10 \%$ hexane in ethyl acetate.

Now a days, the identification of new biological activities and isolation, characterization of new molecules from medicinal plants became the main focus of many research studies ${ }^{[35,36]}$. Several reports of various bioactive molecules from natural resources including medicinal plants that have been indicated in the traditional systems of medicine, with a potential to be useful in the treatment of many diseases have appeared in the literature ${ }^{[37-40]}$. Hence the current research work was carried out and the qualitative phytochemical screening of $Z$. armatum extracts revealed the presence of different phytochemical constituents like steroids, terpenoids, flavonoids, alkaloids, glycosides, phenols, oils, tannins and carbohydrates. The extracts gave negative results for the presence of amino acids and quinones. The ZAME revealed the presence of oils but ZACE and ZAEAE gave negative results. The ZAME showed more phenolic content $23.79 \pm 0.17$ (gallic acid equivalents) and alkaloid content 29.44 \pm $0.82(\mathrm{mg} / \mathrm{g})$ than other extracts. The results are presented in Tables 1 and 2 .

\section{TABLE 1: PHYTOCONSTITUENTS IN DIFFERENT} EXTRACTS OF Z. ARMATUM

\begin{tabular}{lccc}
\hline \multirow{2}{*}{ Phytochemicals } & \multicolumn{3}{c}{ Extracts of Z. armatum } \\
\cline { 2 - 4 } & Chloroform & $\begin{array}{c}\text { Ethyl } \\
\text { acetate }\end{array}$ & Methanol \\
\hline Phytosterols & + & + & + \\
Terpenoids & + & + & + \\
Glycosides & + & + & + \\
Saponins & - & + & + \\
Flavonoids & + & + & + \\
Tannins & - & + & + \\
Carbohydrates & - & + & + \\
Alkaloids & + & + & + \\
Amino acids & - & - & - \\
Oils & - & - & + \\
Quinones & - & - & - \\
Phenols & + & + & + \\
\hline
\end{tabular}

'+' denotes presence and '-' denotes absence
TOTAL PHENOLIC AND CONTENTS OF Z. ARMATUM EXTRACTS

\begin{tabular}{lcc}
\hline $\begin{array}{l}\text { Name of the } \\
\text { extract }\end{array}$ & $\begin{array}{l}\text { Total phenolic } \\
\text { content (GAE) }\end{array}$ & $\begin{array}{l}\text { Total alkaloidal } \\
\text { content }(\mathrm{mg} / \mathrm{g})\end{array}$ \\
\hline Ethyl acetate & $19.48 \pm 0.84$ & $23.92 \pm 0.76$ \\
Chloroform & $20.37 \pm 0.22$ & $19.77 \pm 0.18$ \\
Methanol & $23.79 \pm 0.17$ & $29.44 \pm 0.82$ \\
\hline
\end{tabular}

$\mathrm{n}=3$; mean $\pm \mathrm{SEM}$

The $Z$. armatum root extracts were tested for toxicity in rats at a dose of $2000 \mathrm{mg} / \mathrm{kg}$, which revealed no mortality or any behavioural changes. The hepatoprotective activity of $Z$. armatum extracts was evaluated in the paracetamol-induced liver toxicity model in rats at different concentrations $(125,250$ and $500 \mathrm{mg} / \mathrm{kg}$ ) selected on the basis of the toxicity studies in which $2000 \mathrm{mg} / \mathrm{kg}$ dose of these extracts was found to be safe. The hepatoprotective activity was evaluated by the ability of the extract to produce significant changes in the levels of the liver biomarkers such as AST, ALT, ALP, total bilirubin and total protein that were altered by treatment with paracetamol. Percent protection was calculated as follows, $\%$ protection $=(\mathrm{AST} / \mathrm{ALT} / \mathrm{ALP} /$ total bilirubin in toxicant group)-(AST/ALT/ALP/total bilirubin in drug group+paracetamol group)/(AST/ ALT/ALP/total bilirubin in the paracetamol group)$(\mathrm{AST} / \mathrm{ALT} / \mathrm{ALP} /$ total bilirubin before treatment $) \times 100$.

Group I rats treated with vehicle showed no significant changes in the biomarkers of liver function while group II rats treated with paracetamol showed significant changes in these biomarkers (Table 3). The group III rats administered with paracetamol (200 mg/kg, subcutaneous) and Liv $52(25 \mathrm{mg} / \mathrm{kg}$ per day, per os) showed significant changes in liver biomarker levels compared to group I and II and the percent protection produced by Liv 52 in AST, ALT, ALP, total bilirubin and total protein levels were, $94.79,92.97,96.49,97.57$ and $90.24 \%$, respectively $(\mathrm{p}<0.01)$.

Group IV, V and VI rats were treated with ZAEAE extract at 125,250 and $500 \mathrm{mg} / \mathrm{kg}$ and the percent protection in AST, ALT, ALP, total bilirubin and total protein levels offered by these treatments was 13.24 , $10.78,10.54,9.55 \%$ and $9.76,27.57,26.88,27.33$, $23.44 \%$ and $27.44,52.95,52.19,53.42,45.14$ and $52.44 \%$, respectively $(\mathrm{p}<0.01)$.

Rats of the groups VII, VIII and IX were treated with ZACE extract at 125, 250 and $500 \mathrm{mg} / \mathrm{kg}$ and the treatments offered percent protection for AST, ALT, ALP, total bilirubin and total protein levels to the tune 


\begin{tabular}{|c|c|c|c|c|c|}
\hline \multirow{2}{*}{$\begin{array}{l}\text { Drug treatment } \\
(\mathrm{mg} / \mathrm{kg})\end{array}$} & \multicolumn{5}{|c|}{ Enzymes } \\
\hline & AST (U/l) & ALT (U/l) & $\operatorname{ALP}(U / I)$ & Total bilirubin (mg/dl) & Total protein (g/dl) \\
\hline Control & $89.17 \pm 1.11$ & $52.33 \pm 1.73$ & $183.50 \pm 0.85$ & $0.25 \pm 0.01$ & $6.93 \pm 0.06$ \\
\hline Paracetamol & $332.17 \pm 2.18$ & $159.0 \pm 0.89$ & $529.83 \pm 3.04$ & $2.17 \pm 0.06$ & $4.20 \pm 0.04$ \\
\hline Liv 52 (25) & $101.83 \pm 1.72$ & $59.83 \pm 1.11$ & $195.67 \pm 1.56$ & $0.29 \pm 0.01$ & $6.67 \pm 0.08$ \\
\hline ZAEAE (125) & $300.00 \pm 1.29$ & $147.50 \pm 1.09$ & $493.33 \pm 1.15$ & $1.98 \pm 0.08$ & $4.47 \pm 0.08$ \\
\hline ZAEAE (250) & $265.17 \pm 1.35$ & $130.33 \pm 2.20$ & $435.17 \pm 1.42$ & $1.72 \pm 0.04$ & $4.95 \pm 0.07$ \\
\hline ZAEAE (500) & $203.50 \pm 3.57$ & $103.33 \pm 1.74$ & $344.83 \pm 2.34$ & $1.30 \pm 0.04$ & $5.63 \pm 0.11$ \\
\hline ZACE (125) & $307.50 \pm 2.23$ & $146.17 \pm 1.49$ & $471.83 \pm 2.14$ & $1.93 \pm 0.07$ & $4.60 \pm 0.05$ \\
\hline ZACE (250) & $268.50 \pm 1.98$ & $132.83 \pm 1.40$ & $415.83 \pm 1.96$ & $1.73 \pm 0.07$ & $4.97 \pm 0.10$ \\
\hline ZACE (500) & $208.67 \pm 2.06$ & $105.17 \pm 1.92$ & $306.00 \pm 2.48$ & $1.33 \pm 0.07$ & $5.70 \pm 0.09$ \\
\hline ZAME (125) & $277.50 \pm 2.05$ & $138.67 \pm 0.67$ & $451.33 \pm 2.25$ & $1.80 \pm 0.05$ & $4.80 \pm 0.05$ \\
\hline ZAME (250) & $226.00 \pm 1.65$ & $114.33 \pm 1.61$ & $368.50 \pm 1.82$ & $1.40 \pm 0.05$ & $5.43 \pm 0.06$ \\
\hline ZAME (500) & $169.67 \pm 2.16$ & $89.83 \pm 2.01$ & $294.50 \pm 1.67$ & $1.00 \pm 0.07$ & $6.00 \pm 0.07$ \\
\hline
\end{tabular}

of $10.15,12.03,16.75,12.15 \%$ and $14.63,26.20$, $24.53,32.9222 .57 \%$ and $28.05,50.82,50.47,64.63$, 43.40 and $54.88 \%$, respectively $(\mathrm{p}<0.01)$.

Rats of the groups X, XI and XII were treated with ZAME extract at 125,250 and $500 \mathrm{mg} / \mathrm{kg}$ doses and the treatments showed percent protection of AST, ALT, ALP, total bilirubin and total protein levels to the extent of $22.50,19.06,22.67,19.10 \%$ and 21.95 , $43.69,41.88,46.58,39.93 \%$ and $45.12,66.87,64.84$, $67.95,60.76$ and $65.85 \%$, respectively. These results were shown in Tables 3 , and $4(\mathrm{p}<0.01)$.

Isolated compound ZA-1 was obtained as a white powder with melting point of $210^{\circ}$ and was identified as a compound with formula $\mathrm{C}_{29} \mathrm{H}_{48} \mathrm{O}$ and $\mathrm{m} / z 412.37$ $[\mathrm{M}+\mathrm{H}]$ (fig. 1). The IR spectrum has shown a broad bands at 3321.54, 2923.43, 2852.95, 1459.55 and $1036.52 \mathrm{~cm}^{-1}$ indicating the presence of a hydroxyl and a double bond in the molecule based on ${ }^{1} \mathrm{H}$ NMR, ${ }^{13} \mathrm{C}$ NMR, ESI-MS, FT-IR and $v_{\max }$ spectral data of the compound (fig. 2). The mass spectrum exhibited a molecular ion $[\mathrm{M}]+$ peak at $\mathrm{m} / \mathrm{z} 426$ from EI-MS. The ${ }^{13} \mathrm{C}$ NMR data revealed 30 carbon signals where seven methyls, ten methylene, six methine carbons, five quaternary carbons and two olefinic carbons. The olefinic methylene protons are seen as singlets at 4.68 and $4.55 \mathrm{ppm}$. The ${ }^{13} \mathrm{C}$ NMR data was also in complete agreement with the existence of an isopropenyl group, in particular, the characteristic vinylic carbon atom resonances at 151.2 and $109.3 \mathrm{ppm}$, corresponding to carbon atoms 20 and 29, respectively (fig. 3A). This supported the olefinic methylene protons seen as
TABLE 4: ${ }^{1} \mathrm{H} \quad(400 \mathrm{MHZ}){ }^{13} \mathrm{CNMR} \quad(100 \mathrm{MHZ})$ SPECTRAL DATA OF LUPEOL IN $\mathrm{CDCL}_{3}$

\begin{tabular}{|c|c|c|}
\hline Position & $\delta \mathrm{H}$ & $\delta C$ \\
\hline 1 & $\begin{array}{l}2.41 \\
1.03\end{array}$ & 38.7 \\
\hline 2 & 2.40 & 27.2 \\
\hline $\begin{array}{l}2 \\
3\end{array}$ & $4.68(\mathrm{~s}, 1 \mathrm{H}, 1 \mathrm{OH})$ & 78.7 \\
\hline $\begin{array}{l}3 \\
4\end{array}$ & - & 38.8 \\
\hline $\begin{array}{l}4 \\
5\end{array}$ & 0.73 & 55.2 \\
\hline $\begin{array}{l}5 \\
6\end{array}$ & 2.39 & 18.3 \\
\hline 6 & 2.38 & \\
\hline 7 & 1.92 & 34.2 \\
\hline 8 & - & 40.8 \\
\hline $\begin{array}{l}0 \\
9\end{array}$ & $1.91(\mathrm{dd}, 2 \mathrm{H})$ & 50.4 \\
\hline 10 & - & 37.1 \\
\hline \multirow{2}{*}{11} & 2.73 & 20.9 \\
\hline & 1.91 & \\
\hline \multirow{2}{*}{12} & 3.14 & 25.2 \\
\hline & $1.90(\mathrm{t}, 3 \mathrm{H})$ & \\
\hline 13 & 3.13 & 38.7 \\
\hline 14 & - & 43.0 \\
\hline \multirow{2}{*}{15} & 3.14 & 27.7 \\
\hline & $1.89(\mathrm{~m}, 3 \mathrm{H})$ & \\
\hline 16 & $2.47(\mathrm{~m}, 1 \mathrm{H})$ & 35.5 \\
\hline 17 & - & 43.2 \\
\hline 18 & 1.93 & 48.4 \\
\hline 19 & $4.55(\mathrm{ddd}, 1 \mathrm{H})$ & 48.3 \\
\hline 20 & 245 & \\
\hline 21 & $\begin{array}{c}3.15(\mathrm{~m}, 1 \mathrm{H}) \\
1.91\end{array}$ & 151.2 \\
\hline 22 & $\begin{array}{c}1.93(\mathrm{~m}, 2 \mathrm{H}) \\
1.26\end{array}$ & 29.8 \\
\hline 23 & $0.79(\mathrm{~s}, 3 \mathrm{H})$ & 40.2 \\
\hline & $0.94(\mathrm{~s}, 3 \mathrm{H})$ & 28.0 \\
\hline $\begin{array}{l}24 \\
25\end{array}$ & $0.74(\mathrm{~s}, 3 \mathrm{H})$ & 15.4 \\
\hline 25 & $0.93(\mathrm{~s}, 3 \mathrm{H})$ & 16.1 \\
\hline 26 & $1.89(\mathrm{~s}, 3 \mathrm{H})$ & 16.0 \\
\hline 27 & $1.85(\mathrm{~s}, 2 \mathrm{H})$ & 14.5 \\
\hline 28 & $0.82(\mathrm{~s}, 3 \mathrm{H})$ & 18.0 \\
\hline
\end{tabular}




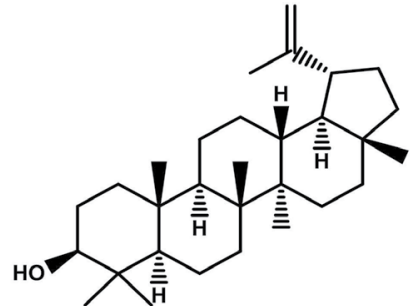

Fig. 1: Structure of lupeol singlets at 4.68 and $4.55 \mathrm{ppm}$ in the ${ }^{1} \mathrm{H}$ NMR spectrum was found to be consistent with known compound lupeol (figs. 3B and Table 4).

The $Z$. armatum extracts of rhizomes showed concentration-dependent hepatoprotective activity by restoring the altered liver biomarker levels due to the hepatic injury caused by paracetamol to normal levels.

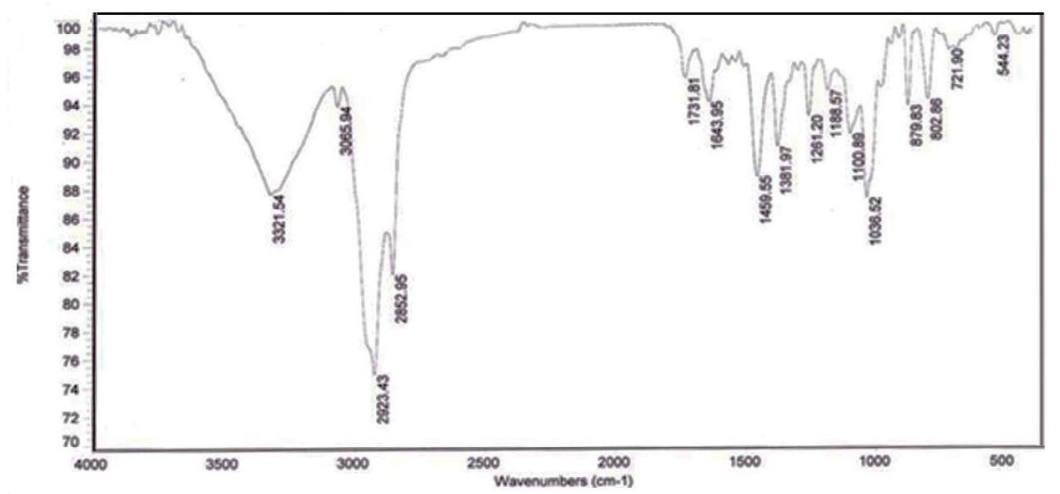

Fig. 2: FTIR spectrum of the compound ZA-1, lupeol

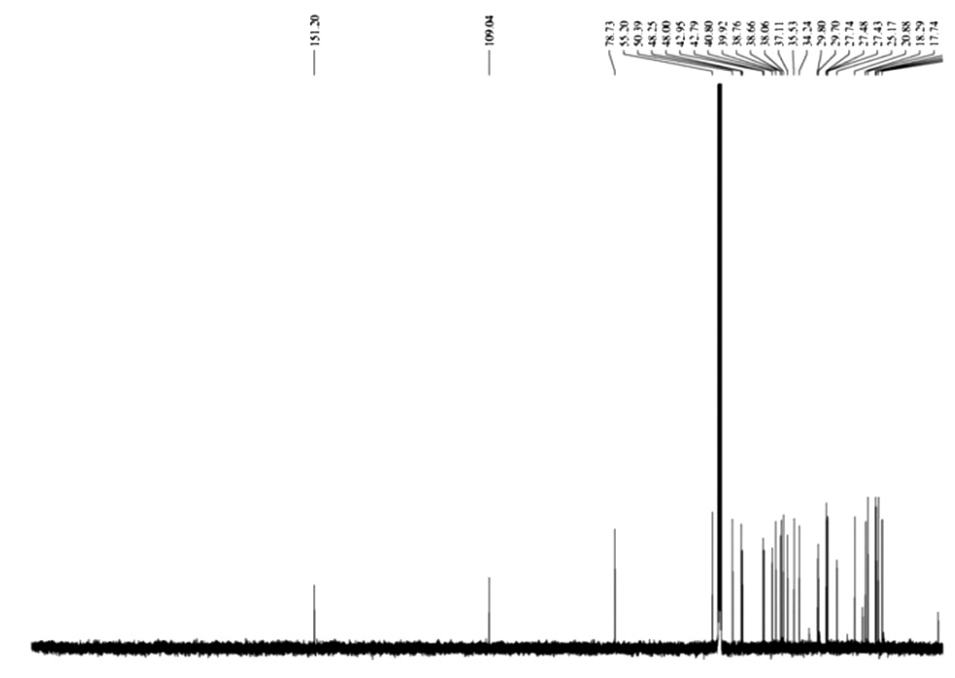

A.
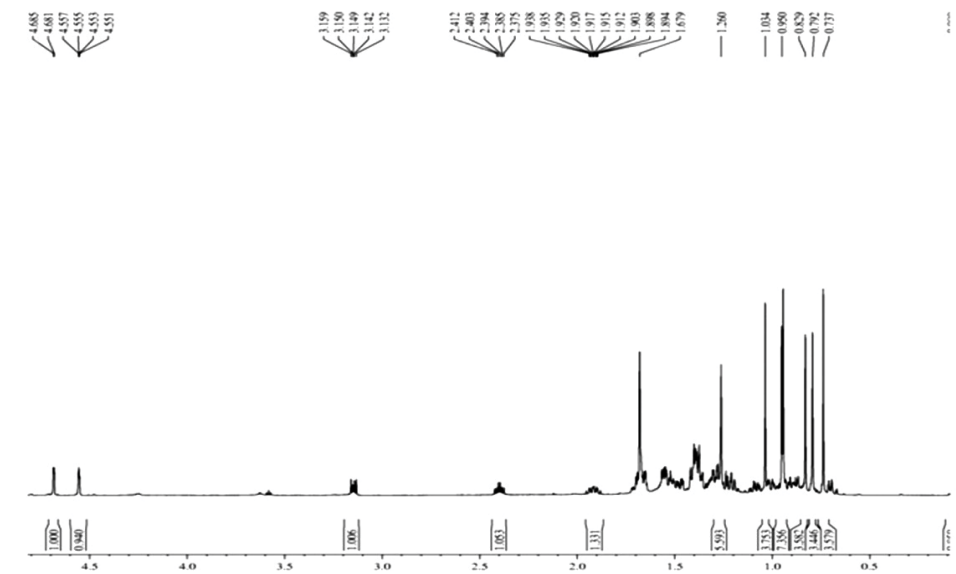

B.

Fig. 3: (A) ${ }^{13} \mathrm{C}$ NMR, and (B) ${ }^{1} \mathrm{H}$ NMR spectrum of the compound ZA-1, lupeol 
TABLE 5: PERCENT PROTECTION OFFERED BY VARIOUS DOSES OF EXTRACTS OF Z. ARMATUM AGAINST PARACETAMOL-INDUCED LIVER TOXICITY

\begin{tabular}{|c|c|c|c|c|c|c|c|c|c|c|}
\hline \multirow{4}{*}{$\begin{array}{l}\text { Name } \\
\text { of the } \\
\text { enzyme }\end{array}$} & \multicolumn{9}{|c|}{ Dose of extract } & \multirow{4}{*}{ Liv 52} \\
\hline & \multicolumn{3}{|c|}{$125 \mathrm{mg} / \mathrm{kg}$} & \multicolumn{3}{|c|}{$250 \mathrm{mg} / \mathrm{kg}$} & \multicolumn{3}{|c|}{$500 \mathrm{mg} / \mathrm{kg}$} & \\
\hline & \multicolumn{3}{|c|}{ Extract type } & \multicolumn{3}{|c|}{ Extract type } & \multicolumn{3}{|c|}{ Extract type } & \\
\hline & $\begin{array}{c}\text { Ethyl } \\
\text { acetate }\end{array}$ & Chloroform & Methanol & $\begin{array}{c}\text { Ethyl } \\
\text { acetate }\end{array}$ & Chloroform & Methanol & $\begin{array}{c}\text { Ethyl } \\
\text { acetate }\end{array}$ & Chloroform & Methanol & \\
\hline AST (U/l) & 13.24 & 10.15 & 22.50 & 27.57 & 26.20 & 43.69 & 52.95 & 50.82 & 66.87 & 94.79 \\
\hline ALT (U/L) & 10.78 & 12.03 & 19.06 & 26.88 & 24.53 & 41.88 & 52.19 & 50.47 & 64.84 & 92.97 \\
\hline ALP (U/l) & 10.54 & 16.75 & 22.67 & 27.33 & 32.92 & 46.58 & 53.42 & 64.63 & 67.95 & 96.49 \\
\hline $\begin{array}{l}\text { Total } \\
\text { bilirubin } \\
\text { (mg/dl) }\end{array}$ & 9.55 & 12.15 & 19.10 & 23.44 & 22.57 & 39.93 & 45.14 & 43.40 & 60.76 & 97.57 \\
\hline $\begin{array}{l}\text { Total } \\
\text { protein } \\
\text { (g/dl) }\end{array}$ & 9.76 & 14.63 & 21.95 & 27.44 & 28.05 & 45.12 & 52.44 & 54.88 & 65.85 & 90.24 \\
\hline
\end{tabular}

Paracetamol is a widely used medication for fever and pain because of its low cost and effectiveness, but its overdose and long-term usage cause adverse effects that include liver damage. The ZAME showed better hepatoprotection compared to the other two extracts in the present study. These extracts showed variations in the percent protection offered for on individual biomarkers, but all extracts showed better protection of ALP levels and lesser protection of total bilirubin levels (Table 3) and as the concentration of extracts increased, the percent protection was also increased (Table 5). Recently it was observed that drug-induced liver toxicity is one of the main causes of mortality ${ }^{[41]}$ and the mechanism of drug-induced liver damage was unclear. Some recent reports indicated that the liver damage is more due to free radical formation induced by excessive use of hepatotoxic drugs. These drugs affect organs functionality, enhance their metabolism leading to free radical formation and breakdown of macro molecules ${ }^{[42]}$. Enhanced production of free radicals, which are more unstable molecules, cause break down of cell membranes of cells including liver cells and alter molecular stabilization ${ }^{[43]}$. In previous reports, $Z$. armatum extracts demonstrated better protective nature through reducing different free radicals, which was found to be more pronounced with the ZAME ${ }^{[28]}$. Lupeol the compound isolated from this plant extract was previously reported to possess different pharmacological activities like antiinflammatory, antiprotozoal, antimicrobial. Qualitative analysis of $Z$. armatum extracts in this investigation revealed the presence of phenolics, alkaloids, terpenoids and glycosides, which were reported to exert a variety of biological activities ${ }^{[44-48]}$. Attempts to isolated pure components from the ZAME resulted in the isolation of lupeol, which was biologically active ${ }^{[49]}$. Phenolic compounds, alkaloids and terpenoids could also have been responsible for the observed hepatoprotective activity as the ZAME had more phenolic and alkaloid content and also simultaneously exerted greater antioxidant and hepatoprotective activities. Previous studies reported that extracts with more phenolic contents possessed more antioxidant activity and hepatoprotective activity ${ }^{[50,51]}$. Results from the current study indicated that it is likely to develop new drugs from the chemical constituents of $Z$. armatum extracts provided the mechanism of action of the hepatoprotective effect exerted is elucidated.

\section{Acknowledgments:}

The authors are grateful to the Rajiv Gandhi National Fellowship, UGC, India for their financial support, authorities of AU College of Pharmaceutical Sciences, Andhra University for providing the necessary facilities to complete current research work. The authors also thank the taxonomist, Dr. K. Madhava Shetty, Department of Botany, Sri Venkateswara University for authenticating the plant material.

\section{Conflicts of interest:}

There is no conflict of interest.

\section{REFERENCES}

1. Law K, Brunt EM. Nonalcoholic fatty liver disease. Clin Liv Dis 2010;14(4):591-604.

2. Rao BG, Rao YV, Rao TM. Hepatoprotective and antioxidant capacity of Melochia corchorifolia extracts. Asian Pac J Trop Med 2013;6:537-43.

3. Björnsson E. Review article: drug-induced liver injury in clinical practice. Aliment Pharmacol Ther 2010;32:3-13. 
4. Hirschfield GM, Thain C, Walmsley M, Brownlee A, Jones DE. Liver disease in the UK. Lancet 2015;385:503.

5. Andrade RJ, Ortega-Alonso A, Lucena MI. Drug-Induced Liver Injury Clinical Consortia: a global research response for a worldwide health challenge. Expert Opin Drug Metab Toxicol 2016;12(6):589-93.

6. Murray KF, Hadzic N, Wirth S, Bassett M, Kelly D. Drugrelated hepatotoxicity and acute liver failure. J Pediatr Gastroenterol Nutr 2008; 47:395-405.

7. Bigoniya P, Singh CS, Shukla A. A comprehensive review of different liver toxicants used in experimental pharmacology. Int J Pharm Sci Drug Res 2009;1(3):124-35.

8. Klaunig JE, Wang Z, Pu X, Zhou S. Oxidative stress and oxidative damage in chemical carcinogenesis. Toxicol Appl Pharmacol 2011;254(2):86-99.

9. Reuben A, Koch DG, Lee WM. Acute liver failure (ALF) secondary to drug induced liver injury (DILI): Causes \& consequences. Hepatology 2009;50:347A.

10. Ventola CL. The antibiotic resistance crisis: part 1: causes and threats. Pharm Ther 2015;40(4):277.

11. Zhang R, Eggleston K, Rotimi V, Zeckhauser RJ. Antibiotic resistance as a global threat: Evidence from China, Kuwait and the United States. Global Health 2006;2:6.

12. Piddock LJ. The crisis of no new antibiotics-what is the way forward? Lancet Infect Dis 2012;12(3):249-53.

13. Shi QW, Li LG, Huo CH, Zhang ML, Wang YF. Study on natural medicinal chemistry and new drug development. Chin Tradit Herb Drugs 2010;41:1583-9.

14. Wright GD. Something new: revisiting natural products in antibiotic drug discovery. Can J Microbiol 2014;60(3):147-54.

15. Butler MS. Natural products to drugs: Natural product-derived compounds in clinical trials. Nat Prod Rep 2008;25:475-516.

16. Zhang LH, Li J. Current situation and developing trends of modernization of traditional Chinese Medicine. Zhejiang Da Xue Xue Bao Yi Xue Ban 2011;40:349-53.

17. Abdullahi AA. Trends and challenges of traditional medicine in Africa. Afr $\mathrm{J}$ Tradit Complement Altern Med 2011;8:115-23.

18. Lone AH, Ahmad T, Anwar M, Sofi G, Imam H, Habib S. Perception of health promotion in Unani herbal medicine. $\mathrm{J}$ Herb Med 2012;2(1):1-5.

19. Patwardhan B. Bridging Ayurveda with evidence-based scientific approaches in medicine. EPMA J 2014;5(1):19.

20. Hong J. Natural product diversity and its role in chemical biology and drug discovery. Curr Opin Chem Biol 2011;15:350-4.

21. Joo YE. Natural product-derived drugs for the treatment of inflammatory bowel diseases. Intestinal Res 2014;12:103-9.

22. Li JW, Vederas JC. Drug discovery and natural products: End of an era or an endless frontier? Science 2009;325:161-5.

23. Gaur RD. Flora of District Garhwal, North Western Himalaya (with ethnobotanical notes). Srinagar: TransMedia; 1999. p. 811.

24. Veda Priya G, Talluri MR, Rao BG. Antibacterial activity of Saponaria officinalis and Zanthoxylu maramatum. Int J Pharmacol Toxicol 2017;5(1):1-4.

25. Barkatullah, Ibrar M, Muhammad N, Rehman IU, Rehman MU, Khan A. Chemical Composition and Biological Screening of Essential Oils of Zanthoxylu marmatum DC Leaves. J Clin Toxicol 2013;3(5):1-6.

26. Muhammad I, Muhammad N, Barkatullah, Khan H, Jahan F, Nadeem Ashraf N. Antinociceptive and anticonvulsant activities of essential oils of Zanthoxylum armatum. Phytopharmacology 2012;2(1):191-8.

27. Minky M, Mahendra Pal S, Kanaya Lal D, Ajudhia Nath K. Cytotoxic and antioxidant activity of Zanthoxylum alatum stem bark and its flavonoid constituents. J Pharmacogn Phytochem 2015;4(4):86-92.

28. Veda Priya G, Talluri MR, Rao BG. Oxidative stress inhibitory aptitude of Saponaria officinalis and Zanthoxylum aramatum. Int J Sci Nat 2017;8(1):75-80.

29. Tiwari P, Kumar B, Kaur M, Kaur G, Kaur H. Phytochemical screening and extraction: A review. Int Pharm Sci 2011;1(1):98106.

30. Evans WC. Trease and Evans Pharmacognosy. 15th ed. London: Elsevier Publisher; 2002. p. 23-67.

31. Singleton VL, Rossi JA. Colorimetry of total phenolics with phosphomolybdic acid phosphotungstic acid reagents. Am J Enol Vitic 1965;16:144-58.

32. Fazel S, Hamidreza $M$, Rouhollah $G$, Verdian-rizi $M$. Spectrophotometric determination of total alkaloids in some Iranian medicinal plants. Thai J Pharm Sci 2008;32:17-20.

33. Organisation for Economic Co-operation and Development. Acute Oral Toxicity-Fixed Dose. 2001. Available from: https:/ntp.niehs.nih.gov/iccvam/suppdocs/feddocs/oecd/ oecd_g1420.pdf.

34. Ramachandra Setty S, Quereshi AA, ViswanathSwamy AH, Patil T, Prakash T, Prabhu K, et al. Hepatoprotective activity of Calotropis procera flowers against paracetamol-induced hepatic injury in rats. Fitoterapia 2007;78:451-4.

35. Mouhssen L. The Success of Natural Products in Drug Discovery. Pharmacol Pharm 2013;4:17-31.

36. Molinari G. Natural products in drug discovery: present status and perspectives. Adv Exp Med Biol 2009;655:13-27.

37. de Albuquerque UP, Monteiro JM, Ramos MA, de Amorim ELC. Medicinal and magic plants from a public market in northeastern Brazil. J Ethnopharmacol 2007;110:76-91.

38. Kalpana P. Rahate, Rajasekaran A. Isolation and Identification of Flavone Aglycones in Roots of Desmostachya bipinnata Stapf. Indian J Pharm Sci 2018;80(3):551-6.

39. Talluri MR, Tadi RS, Battu GR. Therapeutic Protection from Hepatic Injury and Chemical Constituents of Buchanania angustifolia Roxb. Turk J Pharm Sci 2018;15:117-24.

40. Das K, Dang R, Sivaraman G, Ellath RP. Phytochemical Screening for Various Secondary Metabolites, Antioxidant, and Anthelmintic Activity of Coscinium fenestratum Fruit Pulp: A New Biosource for Novel Drug Discovery. Turk J Pharm Sci 2018;15:156-65.

41. Marcellin P, Kutala BK. Liver diseases: A major, neglected global public health problem requiring urgent actions and large-scale screening. Liver Int 2018; 38(Suppl.1):2-6.

42. Li S, Tan H-Y, Wang N, Zhang ZJ, Lao L, Wong CW, et al. The Role of Oxidative Stress and Antioxidants in Liver Diseases. Int J Mol Sci 2015;16(11):26087-124.

43. Es-Safi NE, Ghidouche S, Ducrot PH. Flavonoids: semisynthesis, reactivity, characterization and free radical scavenging activity. Molecules 2007;12:2228-58.

44. Wahle KW, Brown I, Rotondo D, Heys SD. Plant phenolics in the prevention and treatment of cancer. Adv Exp Med Biol 2010;698:36-51.

45. Knekt P, Kumpulainen J, Järvinen R, Rissanen H, Heliövaara M, Reunanen A, et al. Flavonoid intake and risk of chronic diseases. Am J Clin Nutr 2002;76:560-68. 
46. Srikanth $M$, Rao GB. Phytochemical screening and antibacterial activity of Bombex ceiba. J Integral Sci 2018;1(2):10-3.

47. Kaur C, Kapoor HC. Antioxidants in fruits and vegetables- the millennium's health. Int J Food Sci Tech 2001;36:703-25.

48. Hyun TK, Ra JH, Han SH, Kim JS. Antioxidant, Antimicrobial, and Antidiabetic Activities of Crowberry Fruits. Indian J Pharm Sci 2018;80(3):489-95.

49. Margareth B, Gallo C, Miranda J. Sarachine. Biological activities of Lupeol. Int J Biomed Pharm Sci 2009;3:46-66.
50. Gao CY, Tian CR, Zhou R, Zhang RG, Lu YH. Phenolic composition, DNA damage protective activity and hepatoprotective effect of free phenolic extract from Sphallerocarpus gracilis seeds. Int Immunopharmacol 2014;20:238-47.

51. Chen J, Sun H, Sun A, Qin L. Studies of the protective effect and antioxidant mechanism of blueberry anthocyanins in a CC14-induced liver injury model in mice. Food Agric Immunol 2012;3:352-62. 